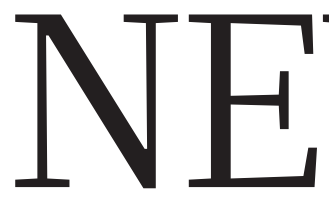

MATHEMATICS Virtual reality makes counterintuitive geometries accessible $\mathbf{p . 4 7 3}$
PoLICY Impeachment of South Korean president sparks push for science change $\mathbf{p . 4 7 4}$
ETHICS African San communities write

rules for scientists $\mathbf{p . 4 7 5}$

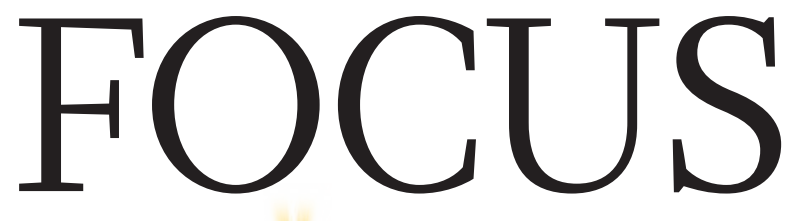

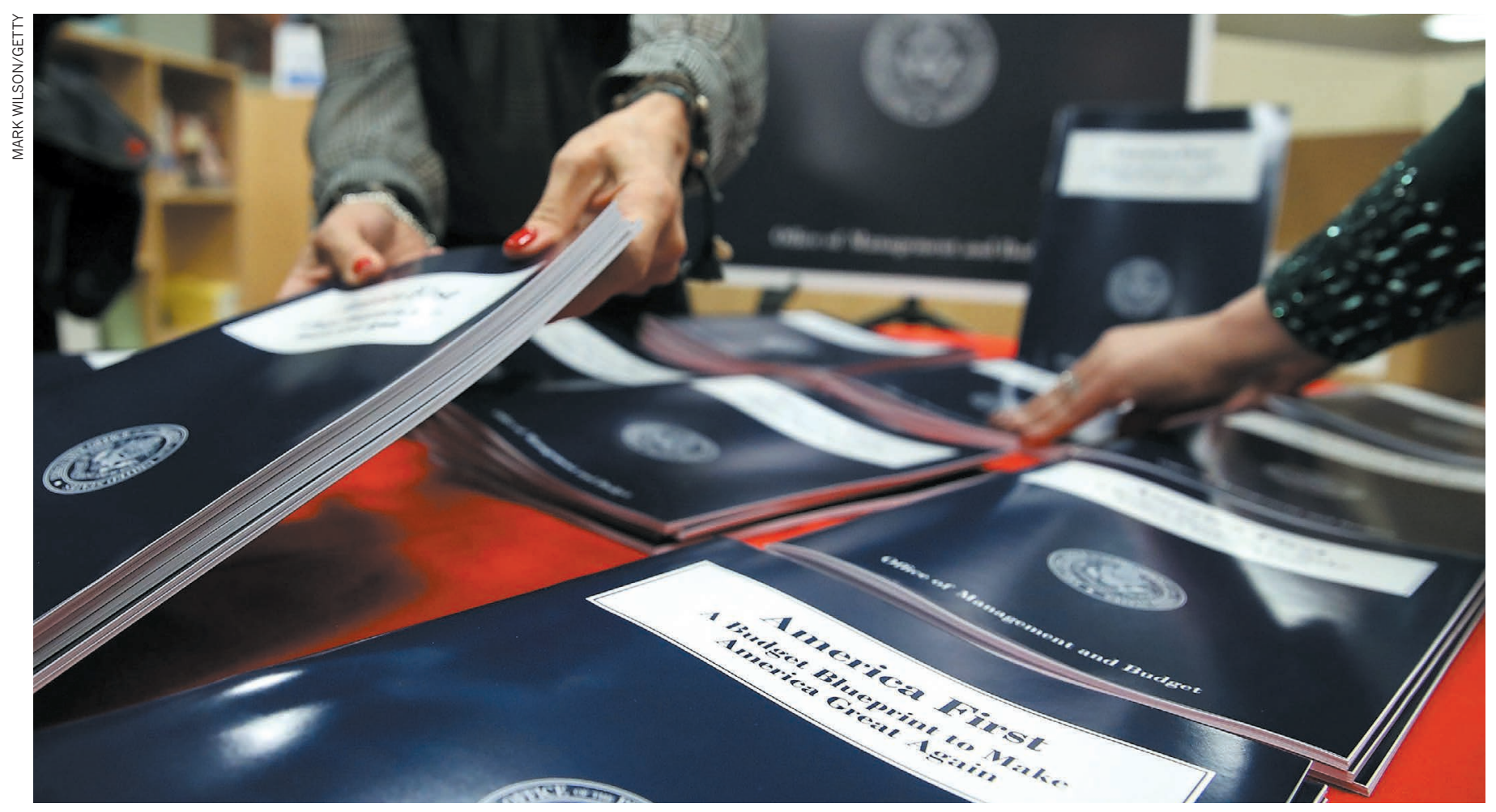

The US president is pushing for deep budget cuts that would affect a broad range of research activities, from climate science to cancer biology.

\title{
POLITICS
}

\section{Science under fire in}

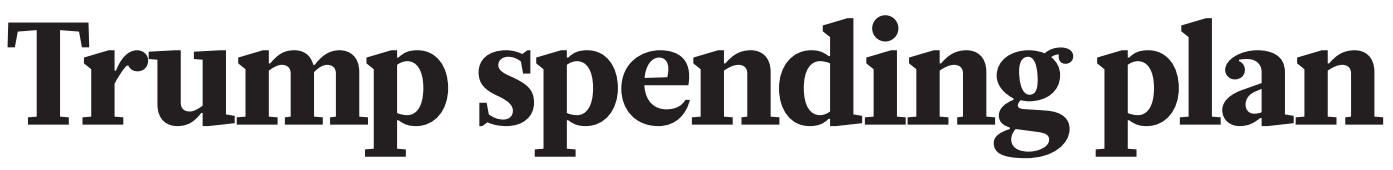

\section{White House proposal would slash support for energy, environment and health research.}

\section{BY SARA REARDON, JEFF TOLLEFSON,}

\section{ALEXANDRA WITZE AND ERIN ROSS}

$\mathrm{W}$

hen it comes to science, there are few winners in US President Donald Trump's first budget proposal. The plan, released on 16 March, calls for double-digit cuts for the Environmental Protection Agency (EPA) and the National Institutes of Health (NIH). It also lays the foundation for a broad shift in US research priorities.

Rumours about the White House proposal have swirled for weeks, alarming many researchers who depend on government funding - and science advocates who worry that the administration's stance will jeopardize US leadership in fields from climate science to cancer biology. It is not clear, however, how much of the plan will survive negotiations in Congress over the coming months.

"Cutting [research and development] funding from our budget is the same as cutting the engines off an airplane that's too heavy for take-off," says Jason Rao, director of international affairs at the American
Society for Microbiology in Washington DC. Also notable is what the budget does not mention: many programmes and even entire agencies, including the National Science Foundation (NSF). The president is expected to release a more complete budget request in May.

The Trump plan would cut funding for the NIH by $18 \%$, to US $\$ 25.9$ billion, making it one of the hardest-hit research agencies. The document calls for a reorganization of the NIH's 27 institutes - including the elimination of the smallest, the Fogarty International Center. 
- "We think there's been mission creep" at the NIH, said Mick Mulvaney, the director of the White House Office of Management and Budget, during a 16 March press briefing. "We think they do things that are outside their core functions."

That did not sit well with biomedicalresearch advocates. "We're pretty upset," says Jennifer Zeitzer, director of legislative relations at the Federation of American Societies for Experimental Biology in Rockville, Maryland. But she is sceptical that Congress, which generally supports biomedical research, will embrace Trump's vision.

\section{ENVIRONMENTAL HAVOC}

The biggest swing of the budget axe - across the entire plan - is aimed at the EPA. The White House wants to slash the agency's $\$ 8.2$-billion budget by $31 \%$, and lay off about 3,200 of its 15,000 staff. The EPA's Office of Research and Development would have its funding reduced by half, from $\$ 483$ million to $\$ 250$ million (see 'On the chopping block').

The proposed cuts, combined with the Trump administration's hostility toward climate and environmental regulations, have sparked fear throughout the agency. "President Trump is always talking about creating jobs, but he is talking about cutting 3,000 people at the EPA," says one agency biologist who is not authorized to talk to the press. "He doesn't even blink an eye."

Jonathan Adler, who heads the Center for Business Law and Regulation at Case Western Reserve University School of Law in Cleveland, Ohio, says that drastically reducing the EPA's budget would undercut the administration's efforts to overhaul environmental policy. Because the agency's decisions can be overruled or modified by federal courts, the only way to fundamentally reorient programmes is to work with Congress to change the law or rewrite regulations. And that requires staff and money, he says.

"If you cut an agency too much, all you've really done is hand the agency's priorities over to the courts and litigants," Adler says. "And I'm not really sure that's what the Trump administration wants."

The White House hopes to cut $5.6 \%$, or $\$ 1.7$ billion, from the Department of Energy and eliminate its Advanced Research Projects Agency-Energy, which funds 'high-risk, high-reward' research. The plan would also slash $\$ 900$ million, or about $20 \%$, from the department's Office of Science, which supports research on topics such as high-energy physics, energy, climate change and biology.

The Trump plan does not include an overall funding target for the National Oceanic and Atmospheric Administration (NOAA). But it would eliminate the agency's long-running, \$73-million Sea Grant programme, which supports 33 US colleges and universities that conduct research, education

\section{ON THE CHOPPING BLOCK}

US President Donald Trump's proposed 2018 budget would dramatically reshape key science agencies.

$\%$ change

(vs fiscal year 2016)

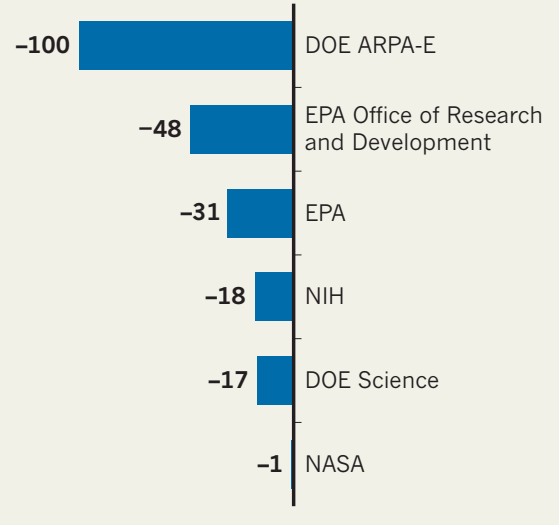

and training on ocean and coastal topics.

The budget expresses support for the agency's "current generation" of weathersatellite programmes, but it offers almost no detail on funding levels. It also pledges to expand the use of commercial data in NOAA weather models, and mentions "savings" that could be achieved by delaying the launch of at least one environmental satellite. An earlier, leaked White House budget document proposed a \$510-million cut to the agency's $\$ 2.3$-billion satellite division, as part of a broader $17 \%$ drop in NOAA's overall funding.

Agency officials are looking at how to restructure the satellite programme to prepare for a smaller budget. Those efforts are

\section{"Trump is always talking about creating jobs, but he is talking about cutting 3,000 people at the EPA."} hampered by the fact that Trump has yet to appoint any senior NOAA leaders. "It's not yet clear what trajectory we are taking," says one senior agency official, who was not authorized to speak publicly.

By contrast, the White House proposed a cut of just under $1 \%$ for NASA - the smallest for any science agency. But it also prescribes a shift in the agency's research priorities to favour "deep-space exploration rather than Earth-centric research".

Within the agency's science directorate, the planetary division is expected to gain the most. Its budget would grow from $\$ 1.6$ billion to $\$ 1.9$ billion. The White House proposal would accelerate NASA's plans to explore Jupiter's moon Europa, an undertaking with powerful backers in Congress including Representative John Culberson, the Texas Republican who chairs the House spending panel that oversees NASA. A plan from the Obama era to drag an asteroid into lunar orbit for close study by astronauts would be cancelled.

Trump also wants to cut spending on Earth-science research from $\$ 1.9$ billion this year to $\$ 1.8$ billion, scrapping four missions. They include the Orbiting Carbon Observatory-3, which would continue NASA's efforts to monitor atmospheric carbon dioxide concentrations from space, and the Earth-observing instruments aboard the Deep Space Climate Observatory. The primary purpose of the satellite, which launched in 2015 , is to track space weather - but it was first proposed as an Earth-monitoring mission in the late 1990s by former vice-president $\mathrm{Al}$ Gore.

Mulvaney was blunt when asked about the cuts to climate research in Trump's plan. "We're not spending money on that any more," he said. "We consider that to be a waste of your money to go out and do that."

Surprisingly, the budget does not mention the NSF. Although the \$7.5-billion agency has traditionally attracted bipartisan support in Congress, Republican lawmakers have sought in recent years to limit the NSF's geoscience and social-science divisions.

The Trump plan adds uncertainty for the agency, which is already struggling to cope with the federal hiring freeze that the president instituted in January. The NSF is scheduled to move its headquarters later this year, and an internal survey suggests that $17 \%$ of its 2,000 staff plan to leave within the next two years because of this. The hiring freeze would prevent the agency from replacing many of these employees.

"I know two individuals who have put off retirement to help out during the hiring freeze," says a programme director, who asked for anonymity to prevent retaliation. "We don't know if they'll stay past the move."

\section{NEXT STOP: CAPITOL HILL}

It is not clear how Congress, which must approve any federal spending plan, will react to the budget proposal. Although the president's fellow Republicans hold majorities in the House of Representatives and the Senate, some have indicated that they will oppose aspects of the Trump budget - including the EPA cuts.

The administration is "proposing nothing less than a dismantlement of several decades of bipartisan support for foundational environmental protections", says Elgie Holstein, a former budget official under president Bill Clinton who works for the Environmental Defense Fund, an advocacy group in New York City. "There are going to be a lot of Republicans, as well as Democrats, on Capitol Hill scratching their heads."

So far, the non-political 'career' employees at the EPA are trying to remain calm and take a conciliatory approach with Trump's political appointees. "We've got four years with this administration," one career official says, "so we are trying to educate rather than confront." 